Vol. 17 (2008): 360-366.

\title{
The effects of different levels of L-carnitine and fat on performance and egg quality of laying hens
}

\author{
Mansour Rezaei ${ }^{1 *}$, Samaneh Dehghani ${ }^{1}$, Janali Ghaffari ${ }^{1}$, and Alizera Haghnazar ${ }^{2}$ \\ ${ }^{1}$ Dept. of Animal Science, Faculty of Animal Science and Fisheries, \\ Sari, Agricultural and Natural Resources Sciences University, PO Box 578, Sari, Iran, \\ ${ }^{2}$ Mazandaran Agricultural Research Center, Sari, Iran \\ *e-mail:m.rezaei@umz.ac.ir
}

\begin{abstract}
L-carnitine is used as feed additive in poultry diets to increase yield and to improve feed efficiency. The major role of L-carnitine appears to be the transport of long-chain fatty acids into mitochondria for $\beta$ oxidation. This experiment was carried out to determine the effects of two levels of fat $\left(10\right.$ and $\left.30 \mathrm{~g} \mathrm{~kg}^{-1} \mathrm{DM}\right)$ and two levels of L-carnitine ( 0 and $\left.250 \mathrm{mg} \mathrm{kg}^{-1}\right)$ on performance, egg quality, and blood parameters of laying hens in a factorial arrangement $(2 \times 2)$ with completely randomized design with six replicates and four laying hens in each replicate. During the experiment feed intake, egg weight, egg production, feed conversion ratio, and some blood parameters (triglyceride, cholesterol, LDL, HDL), egg quality (albumen height, egg shell thickness, egg shell breaking strength), and cholesterol content of eggs were measured. Results of this experiment indicated that supplementation of L-carnitine in laying hens diets had not significant effect on performance, cholesterol content of eggs, but decreased the levels of triglyceride, cholesterol, LDL in blood serum and increased albumen height of eggs significantly $(p<0.05)$. Supplementation of fat significantly increased feed intake and egg weight $(p<0.05)$, but had not significant effect on blood parameters, egg quality and cholesterol content of eggs.
\end{abstract}

Key-words: L-carnitine; fat; egg quality; cholesterol; laying hens

\section{Introduction}

L-carnitine is used as feed additive in poultry diets to increase yield and to improve feed efficiency. Plants and plant-based feedstuffs generally contain very little carnitine compared with animal tissues (Baumgartner and Blum, 1993, 1997). L-carnitine is biosynthesized in vivo from lysine and methionine in the animal tissues (Rebouche and Paulson 1986). Several reports on broiler and pig have demonstrated that growth performance can be improved by feed- 
Vol. 17 (2008): 360-366.

ing supplementary dietary L-carnitine (Weeden et al. 1991, Lettner et al. 1992). Celik et al. (2004) showed that albumen weight and height of eggs were significantly increased by supplementary L-carnitine $\left(50 \mathrm{mg} \mathrm{kg}^{-1}\right)$ in drinking water in laying hens exposed to high ambient temperature $\left(35-37^{\circ} \mathrm{C}\right)$ for 8 h. Kita et al. (2005) reported that supplemental L-carnitine (more than $50 \mathrm{mg} \mathrm{kg}^{-1}$ ) improved yolk weight. Albumen height and Haugh unit were the highest in the $25 \mathrm{mg} \mathrm{kg}^{-1} \mathrm{~L}$-carnitine group. Results of Yalcin et al. (2006) studies showed that adding L-carnitine (100 $\mathrm{mg} \mathrm{kg}^{-1}$ ) alone or in combination with humic substances had not beneficial effects in laying hens. Although L-carnitine is synthesised in the body, conditions such as stress, disease, and physical strain may result in L-carnitine deficiency. Furthermore, the ban on the use of animal-based meal in animal feeding which is the major exogenous source of L-carnitine has resulted in L-carnitine deficiency. This is why efforts are made to supplement plant-based diets in particular with L-carnitine in order to increase the production performance, fertility, physical performance and stress resistance in farm animals. There are inconsistent results about the effect of supplemental fat on performance of laying hens. Several studies showed that increasing dietary energy or supplemental fat decreased feed intake and improved egg weight and feed conversion ratio, but had not significant effect on egg production of laying hens (Bryant et al. 2005, Sohail et al. 2003). In contrast Summers and Leeson $(1983,1993)$ reported that supplemental fat had not significant effect on egg weight of laying hens. As far as we know there is no published article about the interaction of L-carnitine and supplemental fat in laying hens. It was hypothesized that these two substances either alone or in combination would enhance performance and egg traits by acting on nutrient metabolism in laying hens. Measuring blood parameters could be more useful to detect some metabolic effects of L-carnitine and supplemental fat. Therefore the aim of this study was to determine the effects of the dietary L-carnitine and supplemental fat on performance, some blood parameters, and egg traits of laying hens.

\section{Material and methods}

This experiment was conducted on 96 one year old Leghorn-type hens from May to July 2006 in poultry centre, school of Agriculture in Sari, Iran. Leghorn-type laying hens were housed in individual cages and kept under similar management condition. Before beginning of the experiment, egg production of hens was measured individually, and hens were distributed among cages on equal egg production basis. The size of each cage was $(41 \times 23 \times 43 \mathrm{~cm})$ and 4 cages were considered to be one replicate. Diets were formulated based on linear programming by using of UFFDA software. Composition of experimental diets is shown in Table 1. L-carnitine was added to diets at the level of $250 \mathrm{mg} \mathrm{kg}^{-1}$ of diet. Feed and water were provided ad libitum during the experiment. Light condition was 16 h light: 8 $\mathrm{h}$ dark. This experiment lasted 10 weeks. During the experiment daily feed intake, egg production, egg weight, feed conversion ratio was measured. Eggs were collected daily and egg production was calculated on a hen-day basis. Eggs were weighed two times a week individually using all eggs laid for two consecutive days. Mortality was measured throughout the experiment as it occurred. Individual eggs were weighed and their breaking strength and shell thickness were measured bi-weekly. Then the values of albumen height were determined. Eggs were broken onto a smooth level surface and the height of albumen was determined at the two highest points on opposite sides of the yolk, using a standard tripod micrometer. Egg internal quality and shell quality analyses were completed within $24 \mathrm{~h}$ of the eggs being collected. At the end of the experiment blood samples were collected from the vena brachialis under the wing from two hens in each replicate and centrifuged at $4000 \mathrm{rpm}$. Serum was collected and stored at $-20{ }^{\circ} \mathrm{C}$ for determination of serum parameters. Serum concentration of cholesterol, triglyceride, high density lipoprotein (HDL), low density lipoprotein (LDL) were determined (AOAC 1990). Yolk cholesterol was determined as $\mathrm{mg} \mathrm{g}^{-1}$ of yolk. 


\section{AGRICULTURAL AND FOOD SCIENCE}

\section{Rezaei M. et al. L-carnitine supplementation in laying hens diet}

Table 1. Composition of experimental diets $\left(\mathrm{g} \mathrm{kg}^{-1} \mathrm{DM}\right)$

\begin{tabular}{|c|c|c|}
\hline Diets & $10 \mathrm{~g}$ fat & $30 \mathrm{~g}$ fat \\
\hline \multicolumn{3}{|l|}{ Ingredients } \\
\hline Corn & 648 & 581 \\
\hline Soybean meal & 234 & 228 \\
\hline Wheat bran & - & 61 \\
\hline Soybean oil & 10 & 30 \\
\hline Calcium carbonate & 81 & 80 \\
\hline Dicalcium phosphate & 7.10 & 6.40 \\
\hline Vitamin premix ${ }^{1}$ & 2.50 & 2.50 \\
\hline Mineral premix ${ }^{2}$ & 2.50 & 2.50 \\
\hline Sodium chloride & 3.00 & 3.00 \\
\hline Methionine & 5.50 & 5.50 \\
\hline L-carnitine & 0.25 & 0.25 \\
\hline Sand & 5.90 & - \\
\hline Total & 1000 & 1000 \\
\hline
\end{tabular}

Composition

$\mathrm{ME}_{\mathrm{n}}\left(\mathrm{MJ} \mathrm{kg}^{-1} \mathrm{DM}\right)$

11.70

11.70

$\mathrm{CP}$

160

160

Calcium

34.90

33.00

Available Phosphorus

2.50

2.90

Methionine+Cystine

5.80

5.70

Methionine

3.00

3.00

Lysine

8.70

8.00

Arginine

9.80

10.00

${ }^{1}$ provides per kilogram of diet: vitamin A, 12,000 IU; vitamin E, $20 \mathrm{IU}$; menadione, $1.3 \mathrm{mg}$; vitamin $\mathrm{D}_{3}, 2,500 \mathrm{IU}$; riboflavin, $5.5 \mathrm{mg}$; Ca pantothenate, $12 \mathrm{mg}$; nicotinic acid, $50 \mathrm{mg}$; choline chloride, $600 \mathrm{mg}$; vitamin $\mathrm{B}_{12}, 10 \mathrm{mg}$; vitamin $\mathrm{B} 6,3 \mathrm{mg}$; thiamine, $3 \mathrm{mg}$; folic acid, $1.00 \mathrm{mg}$; d-biotin, $0.50 \mathrm{mg}$. ${ }^{2}$ provides per kilogram of diet: Mn, $80 \mathrm{mg}$; Zn, $60 \mathrm{mg}$; Fe, $35 \mathrm{mg}$; Cu, $8 \mathrm{mg}$; Se, $0.60 \mathrm{mg}$.

\section{Statistical analyses}

The model of this experiment was factorial arrangement with completely randomized design. There were 4 treatments ( 2 levels of L-carnitine and 2 levels of fat), 6 replicates per treatment and four hens in each replicate. There were $96(4 \times 6 \times 4)$ laying hens in this experiment. Four hens in each replicate were considered as an experimental unit. Each experimental unit was considered as a replicate.
Normality of data distribution was checked using the Kolmogorov-Smirnov test. The data obtained from this experiment were subjected to factorial analysis of variance (2 factors) by using of SAS software to examine differences between levels of factors (L-carnitine and fat) and interaction between them by General Linear Model procedure (SAS Institute 1998). The differences among means were compared by the Duncan's multiple range test at 
Vol. 17 (2008): 360-366.

$p<0.05$ (Steel and Torrie 1980). Statistical model of this experiment was as follow:

$\mathrm{X}_{\mathrm{ijk}}=\mu+\alpha_{\mathrm{i}}+\beta_{\mathrm{j}}+(\alpha \beta)_{\mathrm{ij}}+\mathrm{e}_{\mathrm{ijk}}$

In this equation the word Xijk is the value of each observation and the words $\mu, \alpha i, \beta_{j},(\alpha \beta)_{i j}$, $e_{i j k}$ represent overall mean, effects of carnitine, fat, interaction of carnitine and fat, and experimental error respectively.

\section{Results and discussion}

During of the experimental period only one laying hen died in group fed with diets containing L-carnitine. No mortality was seen in other groups. Dietary carnitine supplementation has been shown to improve viability due to more efficient utilization of fatty acids in heart muscle (Daskiran and Teeter 2001). Adding L-carnitine to laying hen diets hadn't significant effect on feed intake (Table 2). Similar to the results of the present study, carnitine supplementation had not significant effect on the feed intake of laying hens and laying quails (Rabie et al. 1997, Celik et al. 2004, Yalcin et al. 2005, 2006). There were not significant differences in egg production in hens fed diets supplemented by L-carnitine (Table 2). The results of the present study are also in agreement with the results of some researchers who found that L-carnitine supplementation had not significant effect on egg production of laying hens and laying quails (Celik et al. 2004, Yalcin et al. 2005 and 2006). However, egg production values of laying hens fed $500 \mathrm{mg} \mathrm{kg}^{-1} \mathrm{~L}$-carnitine were higher than those of control group (Bayram et al. 1999). The mean values of egg weight were not affected by dietary treatments (Table 2). Similar to the present trial carnitine supplementation had not significant effect on egg weight of laying hens and laying quails (Rabie et al. 1997, Kita et al. 2005, Yalcin et al. 2006). However, carnitine supplementation in laying quail diets significantly increased egg weight compared to the control group in the study of Yalcin et al. (2005). There were not significant differences in the values of feed conversion ratio between groups in the present study. These results are in agreement with the results of some studies of the supplemental L-carnitine in poultry (Rabie et al. 1997, Celik et al. 2004, Yalcin et al. 2005). In this study, feeding supplemental carnitine had not significant effect on egg shell thickness, and egg shell breaking strength (Table 4). Yalcin et al. (2006) also reported that feeding of supplemental carnitine had not significant effect on egg-shell thickness. Similar to the results of the present study, egg-shell thickness was not affected by carnitine supplementation (Rabie et al. 1997). The values of albumen height were increased by carnitine supplementation. This result is in agreement with the results of previous studies (Rabie et al. 1997, Kita et al. 2005). The mechanism by which the improvement in albumen quality occurred by supplemental dietary L-carnitine has not been clear yet. Based on

Table 2. Effect of different levels of L-carnitine and fat on performance of laying hens

\begin{tabular}{|c|c|c|c|c|c|c|c|c|}
\hline \multirow{2}{*}{$\begin{array}{l}\text { Fat level (g/kg) } \\
\text { L-carnitine level (mg/kg) }\end{array}$} & \multicolumn{2}{|c|}{10} & \multicolumn{2}{|c|}{30} & \multirow[t]{2}{*}{ SEM } & \multicolumn{3}{|c|}{ P-value } \\
\hline & 0 & 250 & 0 & 250 & & Fat & Carnitine & Fat $\times$ Carnitine \\
\hline \multicolumn{9}{|l|}{ Traits } \\
\hline Feed intake $(\mathrm{g} / \mathrm{d})$ & $112.15^{\mathrm{b}}$ & $112.15^{\mathrm{b}}$ & $118.91^{\mathrm{a}}$ & $119.08^{\mathrm{a}}$ & 0.52 & 0.00 & 0.86 & 0.62 \\
\hline Egg production (\%) & 77.83 & 74.00 & 70.70 & 75.67 & 2.50 & 0.24 & 0.74 & 0.08 \\
\hline Egg weight (g) & $59.54^{b}$ & $59.39^{\mathrm{b}}$ & $62.20^{\mathrm{a}}$ & $61.68^{\mathrm{a}}$ & 0.64 & 0.00 & 0.59 & 0.77 \\
\hline Feed conversion ratio & 1.90 & 1.85 & 1.92 & 1.92 & 0.03 & 0.28 & 0.52 & 0.52 \\
\hline
\end{tabular}

Means with different superscripts in each row are significantly different $(p<0.05)$. 


\section{AGRICULTURAL AND FOOD SCIENCE}

\section{Rezaei M. et al. L-carnitine supplementation in laying hens diet}

the results obtained, however the differences in the effect of dietary L-carnitine supplementation on albumen quality may be modified by the difference in laying stages as well as layer strain, dietary sources and environmental conditions. Dietary Lcarnitine might be stimulated to enhance ovomocin secretion resulting in the improvement of albumen height, Haugh unit score and increases storage period and quality of egg for processing (Robinson 1987). Supplementation of carnitine to the laying hen diets had not significant effect on egg cholesterol content (Table 4). Similar to the results of the present trial, carnitine supplementation had not significant effect on egg yolk cholesterol content of laying hens and laying quails (Leibetseder 1995, Yalcin et al. 2005, 2006). Adding Lcarnitine to diets of laying hens reduced triglyceride, cholesterol, and LDL contents of blood serum, but had not significant effect on HDL content (Table 3). These results are in agreement with the results of previous study (Xu et al. 2003). In contrast adding L-carnitine to laying hens diet had not significant effect on serum cholesterol of laying hens (Leibetseder, 1995, Yalcin et al. 2006) and broiler (Lien and Horng 2001). Reducing of triglyceride level in blood serum of hens fed with diets containing 250 $\mathrm{mg} \mathrm{kg}^{-1} \mathrm{~L}$-carnitine is probably related to increasing $\beta$-oxidation of fatty acids in inner mitochondria membranes (Xu et al. 2003). Lien and horng (2001) reported that activity of carnitine palmitoeil transferase enzyme increased in chicks fed with diets containing supplemental L-carnitine. This enzyme has key role in $\beta$-oxidation of lipids and decreases the secretion of VLDL in liver. Increasing supplemental fat increased feed intake in laying hens $(p<0.05)$ (Table 2). Use of supplemental fat in poultry diets reduces the dustiness and increases the palatability and due to these reasons the feed intake increases (Fedd et al. 1960). Increasing supplemental fat had not significant effect on egg

Table 3. Effect of different levels of L-carnitine and fat on some blood parameters of laying hens (mg/dl)

\begin{tabular}{|c|c|c|c|c|c|c|c|c|}
\hline \multirow{2}{*}{$\begin{array}{l}\text { Fat level }(\mathrm{g} / \mathrm{kg}) \\
\text { L-carnitine level }(\mathrm{mg} / \mathrm{kg})\end{array}$} & \multicolumn{2}{|c|}{10} & \multicolumn{2}{|c|}{30} & \multirow[t]{2}{*}{ SEM } & \multicolumn{3}{|c|}{ P-value } \\
\hline & 0 & 250 & 0 & 250 & & Fat & Carnitine & Fat $\times$ Carnitine \\
\hline \multicolumn{9}{|l|}{ Traits } \\
\hline Triglyceride & $66.68^{\mathrm{a}}$ & $58.79^{b}$ & $67.79^{\mathrm{a}}$ & $58.76^{\mathrm{b}}$ & 0.83 & 0.60 & 0.00 & 0.43 \\
\hline Cholesterol & $130.9^{\mathrm{a}}$ & $113.82^{\mathrm{b}}$ & $130.64^{\mathrm{a}}$ & $115.98^{\mathrm{b}}$ & 2.93 & 0.76 & 0.00 & 0.67 \\
\hline LDL & $70.44^{\mathrm{a}}$ & $61.01^{\mathrm{b}}$ & $69.61^{\mathrm{a}}$ & $64.57^{\mathrm{b}}$ & 2.41 & 0.58 & 0.01 & 0.35 \\
\hline HDL & 51.47 & 52.89 & 52.79 & 53.12 & 2.36 & 0.75 & 0.72 & 0.82 \\
\hline
\end{tabular}

Means with different superscripts in each row are significantly different $(p<0.05)$.

Table 4. Effect of different levels of L-carnitine and fat on egg traits of laying hens.

\begin{tabular}{|c|c|c|c|c|c|c|c|c|}
\hline \multirow{2}{*}{$\begin{array}{l}\text { Fat level }(\mathrm{g} / \mathrm{kg}) \\
\text { L-carnitine level }(\mathrm{mg} / \mathrm{kg})\end{array}$} & \multicolumn{2}{|c|}{0} & \multicolumn{2}{|c|}{30} & \multirow[t]{2}{*}{ SEM } & \multicolumn{3}{|c|}{$\mathrm{P}$-value } \\
\hline & 0 & 250 & 0 & 250 & & Fat & Carnitine & Fat $\times$ Carnitine \\
\hline \multicolumn{9}{|l|}{ Traits } \\
\hline Albumen height (mm) & $6.51^{\mathrm{b}}$ & $7.20^{\mathrm{a}}$ & $6.36^{\mathrm{b}}$ & $7.02^{\mathrm{a}}$ & 0.13 & 0.20 & 0.00 & 0.93 \\
\hline Egg shell thickness (mm) & 0.47 & 0.47 & 0.47 & 0.47 & 0.05 & 0.89 & 0.68 & 0.89 \\
\hline $\begin{array}{l}\text { Egg shell breaking } \\
\text { strength }\left(\mathrm{kg} / \mathrm{cm}^{2}\right)\end{array}$ & 0.67 & 0.72 & 0.71 & 0.71 & 0.08 & 0.90 & 0.74 & 0.77 \\
\hline $\begin{array}{l}\text { Cholesterol content of } \\
\text { egg (mg/g yolk) }\end{array}$ & 202.33 & 205.98 & 212.36 & 207.65 & 3.41 & 0.09 & 0.85 & 0.22 \\
\hline
\end{tabular}

Means with different superscripts in each row are significantly different $(p<0.05)$. 
Vol. 17 (2008): 360-366.

production (Table 2). This result was consistent with other studies (Harms et al. 2000, Bryant et al. 2005, and $\mathrm{Wu}$ et al. 2005) who reported that egg production was not affected by supplemental fat or dietary energy. However, Grobas et al. (1999) reported that supplemental fat increased egg production from 38 to 61 weeks of age. Weight gain of hens fed the diets supplemented with fat was significantly higher than of hens fed with diets without fat. Increasing supplemental fat increased egg weight $(p<0.05)$. This result is in agreement with results of several studies (Harms et al. 2000, Sohail et al. 2003, and Bryant et al. 2005). However, several studies reported that increasing supplemental fat had not significant effect on egg weight (Summers and Leeson 1983). The differences among researchers might be due to differences in strains, body weight of laying hens, and composition of supplemental fat. Effect of supplemental fat on feed conversion ratio was not significant (Table 2). Due to enhancing feed intake and egg weight simultaneously with increasing of supplemental fat from 10 to $30 \mathrm{~g} \mathrm{~kg}^{-1}$ the differences between groups was not significant. However, in some researches with increasing the level of supplemental fat feed conversion ratio improved in early phase of egg production (Bryant et al. 2005, Wu et al. 2005). Adding up to $30 \mathrm{~g} \mathrm{~kg}^{-1}$ supplemental fat had not significant effect on albumen quality, egg-shell strength, egg-shell breaking strength, and cholesterol content of egg (Table 4). The egg shell characteristics are quantitative traits and mostly influenced by genetic. Supplemental fat hadn't significant effect on triglyceride, cholesterol, LDL, HDL (Table 3). Dietary fat is known to increase estrogens level in the blood of laying hens (Whitehead et al. 1993) and avian liver increase very low density lipoprotein (VLDL) synthesis under the influence of estrogens. Similar to the results of the present study, effect of supplemental fat on blood parameters were not significant in other experiments (Shafey et al. 2003, Murata et al. 2003). In experiment of Murata et al. (2003) use of diets containing different oil sources (soy, fish, canola, and poultry by-product oil) at 3 percent had not significant effect on plasma total cholesterol, triglyceride, and HDL. Interaction of L-carnitine and supplemental fat on performance is shown in Table 2. Interaction of L-carnitine and supplemental fat had not significant effect on performance parameters. Egg production in hens fed with diets containing $30 \mathrm{~g} \mathrm{~kg}^{-1}$ fat and supplemented with L-carnitine was higher than the other group (75.67 vs 70.70) and the trend showed being significant $(p<0.08)$. Interaction of L-carnitine and fat on some blood parameters are presented in Table 3.). Interaction of L-carnitine and fat on egg traits are shown in Table 4. Increasing the level of Lcarnitine from 0 to $250 \mathrm{mg} \mathrm{kg}^{-1}$ diets improved albumen height significantly $(p<0.05)$, but had not significant effect on egg- shell thickness, shell breaking strength, and cholesterol content of eggs. Yalcin et al. (2005) reported that the feeding of supplemental carnitine to laying quails had not significant effect on egg-shell thickness, shell percentage, yolk and albumen percentage. Similar to the results of the present study, carnitine supplementation had not significant effect on egg yolk cholesterol content of laying hens (Leibetseder 1995) and laying quails (Yalcin et al. 2005). Interaction of L-carnitine and supplemental fat had not significant effect on egg traits (Table 4). Results of the present study showed positive effect of fat on feed intake and egg weight, and significant effect of L-carnitine on decreasing of serum triglyceride, cholesterol, LDL level, and increasing of albumen height of laying hens. Further researches are needed to understand and to clarify the reduction of cholesterol content of egg yolk by carnitine supplementation.

\section{References}

Association of Official Analytical Chemists. AOAC. 1990. Official Methods of Analysis. 14th edn. Arlington, Virginia.

Baumgartner, M. \& Blum, R. 1997. Typical L-carnitine contents in feedstuffs. In L-carnitine Folder, Lonza Ltd., Basel.

Baumgartner, M. \& Blum, R. 1993. L-carnitine in animal nutrition. Pages 413-418 in vitamine und weitere zusatzstoffe bei mensch und tier (vitamins and other supplements for humans and animals). G. Flachowsky and R. Schubert, ed. Friedrich-Schiller University of Jena, Germany. 


\section{AGRICULTURAL AND FOOD SCIENCE}

\section{Rezaei M. et al. L-carnitine supplementation in laying hens diet}

Bayram, I., Akinci, Z. \& Uysal, H. 1999. The effect of L-carnitine and vitamin $C$ supplementation to quail ration on performance and egg production. Journal Faculty Veterinary Medicine University 10: 32-37.

Bryant, M., Wu, G. \& Roland, D.A. 2005. Optimizing dietary energy for profits and performance of two strains of white Leghorn. Page 23 in: International Poultryt Scientific Forum Abstracts, Atlanta, GA, USA.

Celik, L.B. Tekeli, A. \& Oztorkan, O. 2004. Effect of supplemental L-carnitine in drinking water on performance and egg quality of laying hens exposed to a high ambient temperature. Journal of Animal Physiology and Animal Nutrition 88: 229-233.

Daskiran, M. \& Teeter, R.G. 2001. Effects of dietary L-carnitine supplementation on overall performance and carcass characteristics of seven-week-old broiler chickens. Publ. P986. Oklahoma Agric. Exp. Sta. Oklahoma State University. Stillwater. OK, USA.

Fedd, M. R., Waible, P.E \& Burger, R.E.1960. Factors affecting the absorbability of certain dietary fats in the chicks. Journal of Nutrition 70:447-452.

Grobas, S., Mendez, C., De Blas, C. \& Mateos, G.G. 1999. Laying hen productivity as affected by energy, supplemental fat and linoleic acid concentration on performance of laying hens at two ages. British Poultry Science 40: 681-687.

Harms, R.H., Russell, G.B. \& Solan, D.R. 2000. Performance of four strains of commercial layers with major changes in dietary energy. The Journal of Applied Poultry Research 9: 535-541.

Kita, K., Nakajima, S.I. \& Nakagawa, J. 2005. Dietary Lcarnitine supplementation improves albumen quality of laying hens. Journal of Poultry Science 42: 79-83.

Leibetseder, J. 1995. Studies of L-carnitine effects in poultry. Archive Animal Nutrition 48: 97-108.

Lettner, V.F., Zollitsch, W. \& Halbmayer, E. 1992. Use of L-carnitine in the broiler ration. Bodenkultur 43: 161167.

Lien, T.F. \& Horng, Y.M. 2001. The effect of supplementary dietary L-carnitine on the growth performance, serum component, carcass traits and enzyme activities in relation to fatty acid $\beta$-oxidation of broiler chicks. British Poultry Science 42: 92-95.

Murata, L.S., Ariki, J., Machando, C.R., Silva, L. \& Rezode, M.M. 2003. Effects of oils sources on blood lipid parameters of commercial laying hens. Brazilian Journal of Poultry Science 15: 203-206.

Rabie, M. H., Szilagyi, M., Gippert., E., Votissky, E \& Gerndai, D. 1997. Influence of dietary L-carnitine on performance and carcass quality of broiler chickens. Acta Biologica Hungarica 48:241-252.
Rebouchi, C. J. \& Paulson, D. J. 1986. Carnitine metabolism and function in humans. Annual. Review of Nutrition 6: 41-66.

Robinson, D. S. 1987. The chemical basis of albumen quality. In: Egg_quality current problems and recent advances. Poultry Science Symposium (Wells R.G. and Belyavin G.G. eds.) No. 20. pp. 179-191. Butterworths Ltd. London.

SAS Institute. 1998. SAS/STAT User's Guide. Release Version 7.00. SAS Institute Inc. Cary. NC.

Shafey, T.M., Dingle, J. G., MacDonald, M.W. \& Kostner, K. 2005. Effects of type grain and oil supplement on the performance, blood lipoprotein, egg cholesterol and fatty acids of laying hens. International Journal of Poultry Science 2: 200-206.

Sohail, S. S., Bryant, M. M. \& Roland, D.A. 2003. Influence of dietary fat on economic returns of commercial Leghorns. The Journal of Applied Poultry Research 12: $356-361$.

Steel, R. G. D. \& Torrie, J.H 1980. Principle and procedures of statistics. 2th ed. McGrow-Hill book Co. Inc. New York.

Summers, J.D. \& Leeson, S. 1983. Factors effecting early egg size. Poultry Science 62:1155-1159.

Summers, J.D. \& Leeson, S. 1993. Influence of diets varying in nutrient density on the development and reproductive performance of White Leghorn pullets. Poultry Science 72: 1500-1509.

Weeden, T. L., Nelssen, J. A., Hansen, G. E., Fitzner, G. E. \& Goodban, R. D. 1991.The effect of L-carnitine on starter pig performance and carcass composition. Journal of Animal Science 69 (Suppl.) 105 (Abstract).

Whitehead, C. C., Bowman, A.S. \& Griffin, H. D. 1993. Regulation of plasma estrogen by dietary fat in laying hen: Relationship with egg weight. British Poultry Science 34: 999-1010.

Wu, G., Bryant, M. M., Voite, R. A. \& Roland, D. A. 2005. Effect of Mannanase in corn-soy diets on commercial Leghorn in second-cycle hens. Poultry Science 84: 894-897.

Xu, Z. R., Wang, M. Q., Mao, H. X., Zhang, X. A. \& Hu, C. H. 2003. Effects of L-carnitine on growth performance, carcass composition, and metabolism of lipids in male broilers. Poultry Science 82: 408-413.

Yalcin, S., Ergun, M., Ozosy, B., Yalcin, S., Erol, H. \& Onbasilar, I. 2006. The effects of dietary supplementation of L-carnitine and humic substances on performance, egg traits and blood parameters in laying hens. Asian-Australian Journal of Animal Science 19: 1478-1483.

Yalcin, S., Ergun, M., Erol, H., Yalcin, S. \& Ozsoy, B. 2005. Use of L-carnitine and humate in laying quail diets. Acta Veterinaria Hungarica 53: 361-370. 